of Sciences, gives a well-documented account of the manuscripts, documents, prints and other Polish works produced in early times on present German territory. It is clear that in the Middle Ages Polish culture played an important role in those lands now comprising eastern Germany, for many of the Polish kings and noblemen were patrons of learning. Also many scientific and other works by Polish authors were printed in towns as far west as Strasbourg. In the same volume there is an introductory note on the scientific and cultural relations between Germany and Poland by Prof. Aleksander Brückner, of the University of Berlin.

\section{Science in Poland}

Vor. 19 of Nauka Polska (issued simultaneously with vol. 18) contains articles on science in ancient times; problems in writing biographies; current scientific work at Lwów; the position of science in Italy, Greece, Rumania and Lithuania; and a full account of recent activities in England of the British Science Guild, the Association of Scientific Workers and the Parliamentary Science Committee. The volume concludes with a comprehensive international bibliography (20 pages) of "works concerning the psychology and sociology of science" for the years 1928-31. From Prof. T. Mańkowski's report on scientific and cultural life in Lwow at the present time it is clear that, in the faculties for pure science and medicine, modern equipment has been installed and everything is being done to encourage research workers and to see that they are not hampered by lack of facilities. Since the establishment of the Polish Republic, Lwów has become an increasingly important scientific centre in south-east Poland. A polytechnic and medical school existed before the War, but all cultural hife came to a standstill in 1914 and it was not until 1920 that circumstances were favourable for the re-establishment of a university in this city.

\section{Antarctic Exploration}

THe Penola, the vessel of Mr. J. Rymill's antarctic expedition, according to the Times of August 10, was commissioned at Southampton last week and carried out preliminary trials preparatory to sailing for London, where the stores and scientific instruments will be taken on board. The expedition's aeroplane, a three-seater De Havilland Fox Moth, about sixty tons of stores and some sixty Greenland dogs have already been sent out to the Falkland Islands by cargo-steamer. The Penola is due to leave London on September 2 for the Falkland Islands, calling on the way at Monte Video. The staff of the expedition will themselves constitute the crew under command of Lieut. R. E. D. Ryder, R.N. The Penola is a three-masted topsail schooner with two 50 H.P. Diesel engines. Most of the members of the expedition have already had arctic or antarctic experience. While the work will be primarily exploratory, attention will be paid to various scientific problems including plankton, the occurrence of 'heavy water', the sociology of penguins and meteoro- logical work. It is hoped to trace the southern extensions of the Antarctic Andes which are known as the Graham Land islands. Although the expedition hopes to be away for more than two years, the total cost is not expected to exceed $£ 15,000$, which is considerably lower than that of any other previous expedition. There is also news of Admiral Byrd's antarctic expedition; Admiral Byrd himself has been living alone at an observation hut some 120 miles south of his base camp in the Bay of Whales in order to secure continuous meteorological records. He had recently asked to be relieved owing to illness, and a rescue party succeeded in reaching him on August 13.

\section{American Trans-Antarctic Flight}

THE original plan of the Ellsworth Antarctic Expedition for a flight across Antarctica from the Ross Sea to the Weddell Sea and back to the base had to be abandoned last January owing to serious damage to the aeroplane on the pack-ice. Mr. Ellsworth now proposes new plans for the southern summer of 1934-35, and explains them at length in Natural History of July-August 1934. His ship, Wyatt Earp, will reach Deception Island about November 1. From there, Messrs. Ellsworth and Balchen propose to fly southward along the unknown western edge of the Weddell Sea to the ice-barrier at its head and then straight across Antarctica to the Bay of Whales on the Ross Sea, a total distance of 2,800 miles over virtually unexplored areas. The ship will go round to the Ross Sea to pick up the expedition, which will no doubt have the use of Byrd's base in the Bay of Whales. The plane has a maximum speed of 210 miles an hour, and it is proposed to fly at 150 miles an hour. Fully loaded, with pontoons in place of ski, its cruising radius is 3,200 miles. The use of pontoons, which materially increases the weight, is necessary because Deception Island does not offer a land surface sufficiently extensive for a 'take off' for this heavy machine.

\section{American Indian Land-Tenure}

A Movement has been initiated in the United States for the reform of the terms of land-tenure among the Indians. Under the law of 1887 , lands were allotted to the Indians on individual tenure, a system of which they had had no experience under tribal institutions. No sooner had allotment been made than land dealers began to acquire holdings from the Indians, in many instances in exchange for a few bottles of whisky or other articles of little or no value. It is estimated that in less than fifty years the Indians have lost two thirds of their lands, and whole tribes have been reduced to pauperism. A conference has been summoned, it is announced by Science Service, Washington, to discuss this situation, as well as other problems affecting the Indians. It will be attended by representatives of the Indian Rights Association, the National Association on Indian Affairs and many other bodies interested in the welfare of the Indian. The Commissioner of Indian Affairs, Mr. John Collier, will also attend. Special attention will be given to drafting proposals 